\title{
Humanitær intervention \\ i Libyen
}

\section{Tonny Brems Knudsen Eซ Mads Dagnis Jensen}

\section{Baggrunden for humanitær intervention er som regel de stærkes overfald på de svage. Det gælder også i Libyen}

Torsdag den 17. marts klokken ca. 23.30 dansk tid vedtog FN's Sikkerhedsråd til manges overraskelse resolution 1973, som gav en kreds af lande under ledelse af Frankrig, Storbritannien og USA bemyndigelse til at gribe militært ind i Libyen. Samtidig kunne TV-stationen Al-Jazeera vise billeder af en jublende folkemængde på Revolutionspladsen i Benghazi, hovedsædet for opstanden mod Muammar Gaddafis regime.

Der havde ellers hersket stor tvivl $\mathrm{om}$, hvorvidt en sådan resolution ville kunne overvinde særligt kinesisk og russisk modstand i FN's Sikkerhedsråd. Men det kunne den, og tilmed i en vidtgående form, som ikke bare autoriserede den flyveforbudszone over Libyen, som havde været på tale, men også brugen af "alle nødvendige skridt for at beskytte ci- vile og befolkede områder". Hermed bemyndigede FN's Sikkerhedsråd i realiteten en humanitær intervention, der kun udelukkede besættelsestropper i Libyen.

Beslutningen blev taget under indtryk af ikke bare Vestens, men også den Arabiske Ligas stærke anbefaling af et sådant skridt. Ikke mindst fordi Libyens leder havde truet med at afslutte den på dette tidspunkt succesfulde og brutale nedkæmpning af oprøret med en veritabel massakre på Benghazi, opstandens højborg, hvor hans soldater ville gå 'fra hus til hus'.

Den dramatiske situation i dagene op til den 17. marts 2011 har efterhånden fortonet sig i de endeløse NATO-bombardementer af mål i Libyen og den fastlåste situation. Men udgangspunktet er vigtigt at tage med i betragtning, når man vurde- 
rer den humanitære intervention. Det var i 11. time, at de første franske fly viste sig på himlen over Benghazi sent om lørdagen. Gaddafis styrker angreb Benghazi fra flere sider, hans kampvogne havde nået forstæderne, og fra byen kom der desperate appeller til koalitionen om at sende jagerfly på vingerne, inden det var for sent. For sent for den libyske opstand mod Gaddafi. Måske også for sent for 'det arabiske forår' og forhåbningerne om demokratiske forandringer.

\section{Ikke ren altruisme}

Det betyder ikke, at den igangværende humanitære intervention i Libyen skal ses som et udslag af ren altruisme. En massakre i Benghazi ville ikke bare have givet moralske, men også politiske tømmermænd for de stater, som ikke havde viljen til at forhindre en sådan blodig afslutning på den libyske opstand. På tilsvarende vis ville en 'Gaddafi-præcedens' for, hvordan man nedkæmper et arabisk forår, ikke alene have været et tilbageslag for forhåbninger om demokratisering og menneskerettigheder; det ville også have været et tilbageslag for de politiske og $\varnothing$ konomiske gevinster, som Vesten kan gøre sig forhåbninger om vil følge af det arabiske opbrud. Dertil kommer helt konkrete omstændigheder som den franske præsident, Nicolas Sarkozys ønske om at høste indenrigspolitisk aflad for Frankrigs mildest talt uheldige støtte til en række tvivlsomme regimer i den arabiske verden før og sågar i begyndelsen af det arabiske forår.

I den forstand er der intet nyt over den humanitære intervention i Libyen. Der er tale om en cocktail bestående af magt og interesser blandet med værdier og regler ligesom de fleste andre begivenheder $\mathrm{i}$ international politik. Men interventionen i Libyen har stadig et humanitært udgangspunkt og formål i form af resolution 1973 fra FN's Sikkerhedsråd. Det ligner den institutionelle og folkeretlige forankring, som statsledere, diplomater og iagttagere har efterspurgt i årtier i debatter om humanitær intervention og princippet om 'responsibility to protect'.

Er der herved skabt en ny præcedens for humanitær intervention, og er der en løsning på den humanitære interventions klassiske problemstillinger? Eller står det internationale samfund snarere tilbage med nye varianter af gamle problemstillinger samt endnu et eksempel, der splitter det internationale samfund? Disse nøglespørgsmål vil blive behandlet i det følgende, men for at kunne forstå nutiden er det vigtigt at medtage fortidens spøgelser vedrørende humanitær intervention, samt udviklingen siden 1990'erne.

Diskussionen om humanitær intervention i Libyen er blevet hjemsøgt af flere spøgelser fra fortiden, men det er ikke de samme spøgel- 
ser, der har domineret den amerikanske og den europæiske debat.

\section{Irak-spøgelset}

I USA brugte interventionsfløjen Irak-spøgelset fra 1991, hvor præsident George Bush senior tilskyndede shiitter og kurdere til at gøre oprør mod Iraks leder, Saddam Hussein. Men USA greb ikke ind for at hjælpe oprørene, der derfor blev slagtet eller fordrevet af Saddam Husseins soldater. En humanitær intervention i det nordlige Irak i april 1991 reddede kurderne fra en total humanitær katastrofe, men shiitterne blev overladt til deres skæbne. Forud for interventionen i Libyen i marts 2011 argumenterede tilhængerne for, at denne gang måtte USA og Vesten ikke svigte dem, der gør oprør mod despoti.

På den anden side henviste antiinterventionsfløjen til Somalia i 1993, hvor amerikanske soldater blev dræbt og slæbt gennem gaderne i Mogadishu. Dette førte til en doktrin i USA om ikke at indsætte amerikanske soldater på afrikansk jord i fremtiden. En doktrin som de forsvarer den dag i dag under parolen: Aldrig mere et nyt Somalia!

I Europa var det imidlertid ikke Irak 1991 og Somalia 1993, der var de største spøgelser fra fortiden. Her hjemsøgte to andre sager debatten. Den første drejede sig om NATOs humanitære intervention i Kosovo i 1999. Den havde et klart hu- manitært grundlag, men ikke noget mandat fra FN's sikkerhedsråd. Kort fortalt valgte NATO at bombe serbiske mål i 1999. Forinden havde den serbiske leder Slobodan Miloševic indskrænket selvstyret i Kosovo, hvilket endte med en oprørskamp. Som modsvar angreb serbiske styrker albanske landsbyer. Efter mislykkede forhandlinger valgte NATO at iværksætte en humanitær intervention uden et FN-mandat, da Rusland de facto havde nedlagt veto. Angrebet var i strid med FN's Charter, men det blev forsvaret på grundlag af den humanitære folkeret og FN's praksis for at autorisere indgreb for at standse overgreb på civile op gennem 1990'erne.

Men Kosovo delte vandene i det internationale samfund, og særligt Rusland og Kina var vrede over tilsidesættelsen af Sikkerhedsrådet. En vrede der ikke blev mindre af invasionen i Irak i 2003, som både splittede det internationale samfund og de europæiske lande internt. Flere af pro-interventionslandene forsøgte at legitimere interventionen med humanitære argumenter, da det viste sig, at Irak ikke havde masseødelæggelsesvåben. Hermed var princippet om humanitær intervention for alvor i krise: I den europæiske debat om humanitær intervention i Libyen førte dette til et udbredt krav om FN-mandat. Men inden da var retten til humanitær intervention blevet relanceret i en ny form.

Humanitær intervention kan defi- 
neres som tvangsbaseret eller diktatorisk indblanding i en stats indre anliggender med det formål at forhindre folkemord, forbrydelser mod menneskeheden, krigsforbrydelser eller etnisk udrensning.

Dette er i overensstemmelse med faglitteratur om emnet gennem århundreder, hvor essensen er, at der anvendes tvang eller diktat med et humanitært formål. Tvangselementet vil normalt være anvendelse af militær magt.

\section{R2P - responsibility to protect}

Det humanitære element kan i dag præciseres til de fire ovennævnte typer af overgreb mod civile. Dette følger blandt andet af slutdokumentet fra FN's topmøde i 2005, som knæsatte princippet om 'responsibility to protect', i daglig tale R2P, med henblik på at forhindre netop disse overgreb. Princippet er bl.a. udkrystalliseret i FN's Sikkerhedsråds resolution 1674 vedr. beskyttelse af civile i bevæbnede konflikter.

Essensen i folkemord, som beskrives autoritativt allerede i folkemordskonventionen af 1948, er et bevidst forsøg på helt eller delvist at ødelægge en national, etnisk, racemæssig eller religiøs gruppe gennem blandt andet mord, vold og ødelæggelse af livsbetingelser. Forbrydelser mod menneskeheden defineres som systematiske eller omfattende overgreb på en hvilken som helst befolkningsgruppe, mens krigsforbrydel- ser er de overgreb på kæmpende og civile, som beskrives i bl.a. Genevekonventionerne.

Det internationale samfund har inden for og uden for FN's Sikkerhedsråd, med tvang eller samtykke efter pres, samt i varierende omfang og med varierende held, taget skridt til at bringe sådanne overgreb til ophør i en række situationer, fx Irak (1991), Somalia (1992-93), Bosnien (1992-95), Haiti (1994), Rwanda (1994), Kosovo (1998-99), Øst-Timor (1999) samt Darfur (siden 2003).

Indtil 1999 var rammen for sådanne operationer den ret til humanitær intervention, som en række lande har påkaldt sig, og som FN's Sikkerhedsråd i flere tilfælde har været i stand til at autorisere. Men som nævnt hvilede NATO's humanitære intervention i Kosovo i 1999 ikke på noget mandat, og stormagterne kom på kant med hinanden af netop den grund med Rusland samt sekundært Kina og Indien som de stærkest forurettede magter.

Med støtte fra FN's daværende generalsekretær Kofi Annan kom en international kommission nedsat på canadisk initiativ derefter op med idéen om 'responsibility to protect' (R2P) som et forsøg på at genetablere en international konsensus bag muligheden for humanitær intervention. Men nu betegnet som et 'ansvar for at beskytte' frem for en ret til at intervenere, og kun når staten selv åbenlyst har svigtet sit an- 
svar for selv at bringe overgrebene til ophør.

Samtidig omhandler R2P ikke alene ansvaret for at standse overgreb, men også et ansvar for forebyggelse og genopbygning. Hermed blev R2P i sin helhed mindre militaristisk og mere moralsk i sit udtryk end retten til humanitær intervention. Men kernen forblev lige netop en adgang til humanitær intervention, om end som sidste udvej og kun på basis af et FN-mandat. Det er essensen i den autoritative formulering af princippet, som blev vedtaget på FN's topmøde i 2005, jf. slutdokumentets artikel 139, som uddyber det nationale og internationale 'ansvar for at beskytte'.

(139) In this context we are prepared to take collective action, in a timely and decisive manner, through the Security Council, in accordance with the Charter, including Chapter VII, on a case-by-case basis and in cooperation with relevant regional organizations as appropriated, should peaceful means be inadequate and national authorities are manifestly failing to protect their populations from genocide, war crimes, ethnic cleansing and crimes against humanity.

Da slutdokumentet er vedtaget af FN's generalforsamling kan man ikke umiddelbart betegne R2P som folkeret, men som en international norm, som staterne har forpligtet sig til at følge.

Det første, der springer i øjnene, er kravet om FN-mandat og den relativt høje tærskel for militær inter- vention: kun over for de fire omtalte overgreb, kun når staten selv svigter, og kun når fredelige midler er utilstrækkelige.

Derudover skal man hæfte sig ved formuleringen om regional involvering. Dette var i forbindelse med forhandlingerne et væsentligt punkt for en række tredjeverdenslande. Dels fordi den tredje verden naturligt nok ønsker en lokal kontrol med en adgang til humanitær intervention, som mest oplagt vil finde anvendelse i deres del af verden. Dels fordi tilliden til vestlig intervention kunne ligge på et meget lille sted ved vedtagelsen af R2P.

Dette skyldes først og fremmest føromtalte invasion af Irak i 2003, som havde forbitret størstedelen af den tredje verden, opstigende stormagter som Kina, Rusland, Indien og Brasilien, og sågar en række vestlige lande med Frankrig og Tyskland i spidsen. Invasionen af Irak var ganske vist ikke en humanitær intervention, og forsøget på at begrunde den som en sådan af især USA og Storbritannien var for urealistisk til, at det kunne skade princippet om humanitær intervention. Men det kunne selve det forhold, at de involverede lande ifølge den fremherskende internationale opfattelse havde tilsidesat både FN og folkerettens regler vedrørende magtanvendelse, og dermed bragt grundlæggende ordensbærende principper i tvivl.

Kort sagt var det en udbredt hold- 
ning, at Vesten ikke længere kunne betros lederskabet af international militær intervention for det fælles bedste. Således holdt en række magter uden for Vesten på, at enhver indblanding i den humanitære krise i Darfur skulle hvile på samtykke fra den sudanesiske regering, og at tropperne og de politiske aftaler skulle basere sig på regionale beslutninger og regionalt ejerskab, her den Afrikanske Union. Det har været holdningen fra krisens begyndelse i 2003 og frem til i dag.

Set i det lys var det højst overraskende, at de vestlige stormagter pludselig kom ud af den karantæne vedrørende lederskab af humanitære interventioner, som en del af verden anført af Rusland og Kina reelt havde sat Vesten i op gennem 2000'erne.

\section{Benghazi - ny chance}

Da Benghazi stod over for en massakre, og skeptiske stormagter stod til at få ansvaret for en handlingslammelse, fik Vesten med fransk, britisk og amerikansk lederskab på sin vis en ny chance. Dette rejser umiddelbart en række interessante spørgsmål, herunder om R2P nu omsider kan virke efter hensigten, om problemerne ved humanitær intervention hermed har fundet en overordnet løsning, og om Libyen virkelig bliver den case, der genføder princippet om humanitær intervention, eller måske snarere den der kan gå hen og tilføje dette princip fornyet skade?

Resolution 1973 af 17. marts 2011 vedr. situationen i Libyen ligner på mange måder de resolutioner vedrørende humanitære interventioner, som FN's Sikkerhedsråd vedtog $\mathrm{i}$ 1990'erne: Sikkerhedsrådet autoriserer anvendelsen af militære midler til opnåelsen af humanitære formål på basis af kapitel VII i FN's Charter. Selve princippet om 'responsibility to protect' omtales kun i præamblen, hvortil kommer anvendelse af ordet 'protect' i forbindelse med såvel Libyens egne forpligtigelser som Sikkerhedsrådets autorisering af militære midler.

Alligevel er R2P af stor betydning for forståelsen af såvel resolutionen som det spil, der gik forud. Man kan argumentere for, at R2P kom til at fungere efter hensigten i mindst tre henseender.

For det første har princippet fungeret som en moralsk løftestang: Et ansvar som en række stater med Frankrig, Storbritannien og senere USA i spidsen kunne påberåbe sig med støtte fra FN's generalsekretær, og et ansvar som uundgåeligt lagde et pres på veto-magterne Kina og Rusland samt de ikke-permanente medlemmer Indien og Brasilien. Det moralske pres bestod dels i, at de fire BRIK-lande risikerede at komme til at stå med hovedansvaret for en eventuel massakre i Benghazi, dersom de havde blokeret for det fransk-britisk-amerikanske tilbud om 
at gribe ind. Dels i den omstændighed, at såvel de permanente medlemmer af sikkerhedsrådet Kina og Rusland som kandidatlandene Brasilien og Indien har et stærkt behov for at fremstå som ansvarlige stormagter.

Den manglende vilje til at gribe ind i Bahrain og Syrien svækker til gengæld et generelt argument om R2P's moralske styrke. Libyen er på flere måder et særligt tilfælde, hvor militær intervention forekom at være en farbar løsning over for en exceptionelt isoleret leder. Men man kan dog konkludere, at R2P har tilstrækkelig moralsk styrke til at gøre en forskel under gunstige omstændigheder.

For det andet kom den humanitære intervention i Libyen til at hvile på et klart og vidtgående mandat fra FN's Sikkerhedsråd, jæunfør stk. 4 i resolution 1973:

Authorizes Member States that have notified the Secretary-General, acting nationally or through regional organizations or arrangements, and acting in cooperation with the Secretary-General, to take all necessary measures (...) to protect civilians and civilian populated areas under threat of attack in the Libyan Arab Jamahiriya, including Benghazi, while excluding a foreign occupation force of any form on any part of Libyan territory (...).

Der er altså ingen tvivl om, at Sikkerhedsrådet bemyndigede brugen af alle nødvendige midler bortset fra en militær besættelse til beskyttelse af civile og beboede områder under angreb. Heller ikke selv om det kan diskuteres, præcis hvad der er nødvendigt for at bringe sådanne angreb til ophør. Men situationen er under alle omstændigheder radikalt forskellig fra situationen i 1999, hvor NATO intervenerede i Kosovo fra luften uden basis i en autorisation fra FN's Sikkerhedsråd.

Den humanitære intervention i Libyen blev hermed den første FNautoriserede humanitære intervention uden en form for samtykke fra den stat, det handler om, siden midten af 1990'erne, hvor man så FNmandater til tvangsmæssige indgreb i Bosnien, Rwanda og Haiti. Mandatet til interventionen i Libyen var et krav fra ikke mindst USA. En mulig tolkning er således, at konsensus om FN-autoriseret humanitær intervention fra starten og midten af 1990'erne er blevet genetableret, sådan som det er forudset i R2P som vedtaget i 2005. Humanitære interventioner uden autorisation fra Sikkerhedsrådet kan naturligvis ikke udelukkes, men de vestlige stormagter er i dag meget bevidste om, at legitimiteten afhænger af mandat fra FN.

For det tredje tyder meget på, at den for den ikke-vestlige verden centrale passus om regional inddragelse har været udslagsgivende i tilfældet $\mathrm{Li}$ byen. Regionalt ejerskab er hvad den Afrikanske Union, en lang række tredjeverdenslande og skeptiske stormagter har krævet igen og igen, når talen er faldet på humanitær in- 
tervention. Og regionalt ejerskab var, hvad de fik i tilfældet Libyen. Nøglen til resolution 1973, der gav grønt lys for en humanitær intervention, var således støtte fra de regionale organisationer: Den Arabiske Liga, Den Afrikanske Union, og Den Islamiske Konferenceorganisation. Alle tre regionale organisationer fordømte den uforholdsmæssige brug af vold mod civile i Libyen allerede inden vedtagelsen af sikkerhedsrådsresolution 1970, som blandt andet tog det vidtgående skridt at henvise situationen i Libyen til Den Internationale Straffedomstol (ICC) i Haag. Det gjorde et stærkt indtryk på den tredje verdens medlemmer af Sikkerhedsrådet. Indien signalerede således, at man ikke havde kunnet støtte henvisningen til ICC uden den stærke regionale opbakning.

Det samme gjorde sig gældende i forbindelse med vedtagelsen af resolution 1973 og dermed den humanitære intervention i Libyen. Den kinesiske $\mathrm{FN}$-ambassadør begrundede sit lands beslutning om at afstå fra at stemme - og altså lade beslutningen om militær intervention passere gennem Sikkerhedsrådet - således:

"We support the Security Council's adoption of appropriate and necessary action to stabilize the situation in Libya as soon as possible, and to halt acts of violence against civilians. (...) China is always against the use of force in international relations. (...) China has serious diffi- culty with parts of the resolution. Meanwhile, China attaches great importance to the relevant position by the 22-member Arab League on the establishment of a no-fly zone over Libya. We also attach great importance to the position of African countries and the African Union. In view of this, and considering the special circumstances surrounding the situation in Libya, China abstained from the voting on resolution 1973."

Tilsvarende tilkendegivelser kom fra Rusland og Brasilien, mens Indien som sagt understregede betydningen af den regionale opbakning i forbindelse med vedtagelsen af den ligeledes vidtgående resolution 1970.

I alle tilfælde er det påfaldende, at det netop er den regionale støtte til militær magtanvendelse, herunder den Arabiske Ligas anbefaling af dette direkte til FN's Sikkerhedsråd, som er udslagsgivende. Udslagsgivende for balancen mellem en udtalt bekymring for Libyens civile og en lige så udtalt bekymring for underminering af suverænitetsprincippet, risikoen for misbrug samt skadelige konsekvenser af militære indgreb. Den regionale anbefaling og medvirken understreges også af en række tredjeverdenslande, herunder Sydafrika, Columbia, Nigeria og Libanon, samt de vestlige stormagter Frankrig, Storbritannien og USA.

Da det først var lykkedes Frankrig, 
Storbritannien og USA at få flere af de regionale organisationer med på idéen om humanitær intervention i Libyen, var det vanskeligt for Rusland og Kina at nedlægge veto, ikke mindst under indtryk af den overhængende risiko for en omfattende massakre. I den situation fandt de mere kritiske lande det ikke rimeligt eller politisk holdbart at stemme imod en resolution. Omvendt var det ikke nok til at overbevise de fire 'nye' stormagter om, at de skulle give resolutionen deres fulde støtte frem for den form for samtykke, som ligger i, at man afstår fra at stemme. BRIK-landende - Brasilien, Rusland, Indien og Kina - afstod i samlet flok (ligesom Tyskland). Heri ligger der et vigtigt signal til Vesten om ikke at overspille princippet om humanitær intervention.

\section{Præcedens}

Selvom den humanitære intervention i Libyen på flere måder er unik, har den mulighed for at danne politisk og institutionel præcedens. Mest oplagt en præcedens som reetablerer og præciserer den praksis for humanitær intervention, som blev udviklet i 1990'erne. Beslutninger om humanitær intervention vil altid afhænge af de militære muligheder og de politiske interesser, men princippet om 'responsibilty to protect' trækker, trods dets dobbelte konstruktion med staten som første ansvarlig og det internationale sam- fund som anden ansvarlig, mere mod diplomatisk indblanding og militær intervention end det modsatte.

Dertil kommer, at kravet om FNmandat er blevet styrket med den humanitære intervention i Libyen. Ikke alene fordi der kom et mandat, men også fordi de vestlige magter klart meldte ud, at der skulle være et sådant mandat. Der er en verden til forskel på at foretrække et FNmandat (Bush-regeringen forud for angrebet på Irak) og så insistere på et som betingelse for handling (Obama-regeringen forud for interventionen i Libyen). Humanitær intervention uden $\mathrm{FN}$-mandat kan ikke udelukkes (Kosovo 1999), men det er ikke den model, der er trukket op efter Libyen.

Sidst men ikke mindst er den tredje verdens krav om regionalt ejerskab blevet kraftigt underbygget med interventionen i Libyen. De Vestlige stormagter vidste, at Kinas og Ruslands stilling i Sikkerhedsrådet ville afhænge af et regionalt ejerskab. Dette kan vise sig at være den klareste, positive præcedens fra interventionen i Libyen. Positiv fordi det øger international konsensus bag humanitær intervention samt bidrager til legitimitet, repræsentativitet og en form for 'checks and balances'.

Argumentet om præcedens skal tages med det forbehold, at humanitær intervention i sig selv er en undtagelse til hovedreglen om ikke-in- 
tervention. Sådan er FN's charter og folkeretten indrettet, og sådan er den internationale praksis. Humanitære interventioner vil fortsat være relativt sjældne i international politik.

\section{Gamle problemer, nye varianter}

Den humanitære intervention i Libyen kan endog vise sig at blive den sidste i lang tid. Det skyldes blandt andet, at NATO og resten af koalitionen i skrivende stund står med flere alvorlige problemer i Libyen. Problemerne skyldes konfliktens natur: Når befolkningsgrupper gør oprør mod autoritære regimer og tager våben $i$ hånd for at forsvare sig mod repressalier, så bliver humanitær intervention automatisk til en intervention i en borgerkrig. Og når man kører fast i en borgerkrig, kommer angreb på regimet, frem for forsvar af civile i snæver forstand, let på tale.

Hermed er den humanitære interventions problemstillinger, som har været diskuteret i århundreder, aktuel i nye varianter, eller måske blot varianter, som man har set før, men allerede glemt igen. De traditionelle problemer omfatter risikoen for, at humanitære interventioner fører til undergravning af suverænitetsprincippet, misbrug af det humanitære mandat og konflikt mellem stormagterne. Hertil kommer operationelle problemer såsom risikoen for militære og civile tab samt manglende succes med opnåelsen af det humanitære formål.

Med et FN-mandat til militær magtanvendelse samt regional opbakning er de mest fundamentale problemer afværget. Der er tale om en undtagelse i forhold til suverænitetsprincippet, som følger spillereglerne, og som gør anklager om misbrug af princippet om humanitær intervention vanskelige. Men der er en risiko for, at koalitionen overskrider mandatet set fra de kritiske staters synspunkt. Eller at disse stater simpelthen kommer til den konklusion, at humanitær intervention uundgåeligt fører uheldige politiske konsekvenser med sig. Disse handler mest oplagt om borgerkrig og regimeskifte.

Baggrunden for humanitær intervention er som regel de stærkes overfald på de svage. Det var også udgangspunktet i Libyen. Sådanne overgreb kan i nogle tilfælde forhindres med militær intervention, men hvis de skal bringes permanent til ophør, kræver det i reglen, at de svage gøres til de stærke. Politisk skal det altså være acceptabelt at tage parti og militært skal det være muligt at ændre magtbalancen mellem de to sider.

Den amerikanske udenrigsminister Hilary Clinton understregede tidligt, at bombardementerne fortsætter, indtil Gaddafi stopper al voldsanvendelse mod civile og trækker sine styrker væk fra byerne. Dette er grundlæggende konsistent 
med resolution 1973 og bemyndigelsen til at "tage alle nødvendige skridt for at beskytte civile og befolkede områder, som trues af angreb".

Dette ændrer dog ikke ved, at NATO og koalitionen i praksis er blevet luftvåben for oprørerne. Luftangrebene til forsvar af Benghazi, Misrata og andre byer suppleres endda med offensive angreb på mål i eksempelvis hovedstaden Tripoli.

\section{Part i borgerkrig}

For koalitionen er regimets fald en forudsætning for at få standset overgrebene på befolkningen. Hermed er det vanskeligt at adskille humanitær intervention fra det at tage parti i en borgerkrig.

Der er dog et vist politisk spillerum for humanitære interventioner, som har et FN-mandat. Humanitære interventioner må ikke have politiske årsager, men det er en almindelig antagelse, at de godt må have politiske konsekvenser. Alt andet er næsten uundgåeligt. Det vidste de stater, der stemte for resolution 1973, eller lod den passere, naturligvis godt. Spørgsmålet er så, hvordan koalitionen kan fremkalde et så markant politisk resultat, som Gaddafis afgang, uden at dette vil opleves som illegitimt blandt skeptiske stormagter og dele af den tredje verden.

En radikal tolkning af resolution $1973 \mathrm{er}$, at den tillader alle skridt, som er nødvendige for at få stoppet overgrebene på civile. Herunder også offensive angreb på regimets ledelse. Objektivt vurderet er den tolkning tvivlsom. Problemet er ikke så meget ræsonnementet og identifikationen af militære mål, men simpelthen ordlyden af resolution 1973, som autoriserer brugen af de nødvendige midler til beskyttelse af civile, som trues af angreb. Hermed er der lagt op til brug af magt i direkte forsvar af civile, ikke til offensive angreb for at fremtvinge et regimeskifte. Modargumentet er naturligvis, at risikoen for nye angreb på civile er overhængende, medmindre regimet fjernes.

Men det argument tæller kun i forhold til spørgsmålet om international legitimitet, hvis man kan få international accept. Det samme gælder anvendelsen af landstyrker. Mandatet i resolution 1973 udelukker rent faktisk ikke indsættelsen af landstyrker, men "en udenlandsk besættelsesstyrke af enhver form i enhver del af libysk territorium". En besættelsesstyrke er noget andet end indsættelse af tropper til beskyttelse af civile. Såfremt Sikkerhedsrådet $\varnothing n s k e d e$ at udelukke landsstyrker, ville det have stået i resolutionen. Det løser dog ikke koalitionens problem, for rationalet bag indsættelsen af landstyrker ville næppe være rent defensive handlinger, men at udvirke Gaddafis fald.

Hermed er vi tilbage ved spørgsmålet om, hvad de mere skeptiske dele af det internationale samfund 
kan gå med til. Den sydafrikanske FN-ambassadørs udtalelser i forbindelse med vedtagelsen af resolution 1973 giver en klar indikation på svaret:

"As a matter of principle, we have supported the resolution with the necessary caveats to preserve the sovereignty and territorial integrity of Libya and reject any foreign occupation or unilateral military intervention under the pretext of protecting civilians. It is our hope that this resolution will be implemented in full respect for both its letter and spirit."

De interventionsskeptiske lande forventer med andre ord en humanitær fortolkning i overensstemmelse med resolutionens ordlyd og intentioner. De forventer også en løbende konsultation om, hvordan mandatet fortolkes. Et vigtigt signal, som Vesten ikke må overhøre. De skeptiske lande vil ikke have en præcedens for intervention til fordel for regimeskifte. Og de vil ikke have en tilbagevenden til situationen i 1990' erne, hvor intervention for 'det fælles bedste' altovervejende blev gennemtrumfet af Vesten. Derfor skal styret helst væltes med Benghazi i en hovedrolle, og derfor er fortsat regional opbakning essentiel.

Hensynet til den internationale konsensus om humanitær intervention i almindelighed og interventionen i Libyen i særdeleshed taler for, at koalitionen bør modstå fristelsen til at søge at forcere regimets ende- ligt med militære midler. Omvendt taler hensynet til Libyens befolkning for, at det ikke trækkes i langdrag. Det samme gør koalitionens ønske om at få interventionen afsluttet og helst med succes. Dette er dilemmaet.

Hvis valget falder på militær optrapning er vejen frem for koalitionen maksimal udnyttelse af Overgangsrådets voksende legitimitet, fastholdelse af regional opbakning og tæt konsultation med de skeptiske stormagter med henblik på varetagelse af deres interesser og principielle synspunkter. Det gælder ikke mindst, når der skal forhandles en ordning for stabilisering og rekonstruktion af Libyen med eller - må man stærkt formode - uden Gaddafi. Her husker de vestlige stormagter forhåbentlig på, at det var en eklatant fejltagelse at søge at holde Rusland ude af rekonstruktionen af Kosovo efter afslutningen af den humanitære intervention i 1999.

\section{Humanitær intervention fremover}

Med tanke på den udbredte skepsis over for humanitær intervention op gennem 2000'erne er der en risiko for, at en række stater vil drage den konklusion, at Vesten ikke kunne overholde formuleringerne i Sikkerhedsrådets resolution 1973 og ånden i R2P. I værste fald vil stater som Kina, Rusland, Indien og Brasilien drage den konsekvens, at man ikke kan acceptere humanitære interven- 
tioner i fremtiden. Det ville være en skam, når de vestlige stormagter og koalitionen er gået ud i et berettiget humanitært ærinde med FN-mandatet som en reel forudsætning for handling.

Det er netop med et klart udgangspunkt i de folkeretlige spilleregler til forskel fra rent vestlige værdier eller nationale interesser, at man kan kræve, at andre stater skal kunne se forskel på aggression og værdiimperialisme, som mange lande mente at kunne se i invasionen af Irak 2003, og humanitær intervention, som de fleste formentlig fortsat kan anerkende i tilfældet Libyen 2011. Det er ligeledes med udgangspunkt i de folkeretlige spilleregler, at man kan trække forskellen op mellem en intervention, som søger en ny politisk orden for de intervenerende landes egen skyld, og en intervention, som fører til en ny politisk orden, fordi det er den eneste måde, hvorpå folkerettens humanitære minimumsstandarder kan sikres på længere sigt.

\section{Væltes af sine egne?}

Det mest sandsynlige er fortsat, at Gaddafi bliver væltet af sine egne. Kombinationen af militært og politisk pres, hvor Overgangsrådets na- tionale legitimitet og internationale anerkendelse øges skridt for skridt stiller Gaddafi i en mere og mere umulig situation. Dertil kommer anklagerne om Gaddafis involvering i krigsforbrydelser og forbrydelser mod menneskeheden fra blandt andre ICC. Disse anklager gør det vanskeligt for de interventionsskeptiske stater at kræve, at Gaddafis styre respekteres som den suveræne og legitime repræsentant for Libyen.

Om vejen ud af den libyske labyrint bliver lang eller kort er vanskeligt at forudse i skrivende stund, men der er meget på spil, herunder dels hensynet til den libyske befolkning, dels hensynet til den fremtidige enighed om humanitær intervention og militær magtanvendelse som sådan.

Artiklen er afsluttet den 27. juni 2011.

Tonny Brems Knudsen er lektor i international politik ved Institut for Statskundskab, Aarhus Universitet.

Mads Dagnis Jensen er ph.d.-stipendiat ved det Europaiske Universitetsinstitut $i$ Firenze.

Litteraturliste kan fås ved henvendelse til brita@udenrigs.dk 